$\begin{array}{ll} & \text { Etnográfica } \\ \text { etnográfica } & \text { Revista do Centro em Rede de Investigação em }\end{array}$

Antropologia

vol. $12(2) \mid 2008$

Vol. $12(2)$

\title{
A energia da antropologia: seis cartas de Jorge Dias para Ernesto Veiga de Oliveira
}

João Leal

\section{OpenEdition}

\section{Journals}

Electronic version

URL: https://journals.openedition.org/etnografica/1814

DOI: 10.4000/etnografica.1814

ISSN: 2182-2891

\section{Publisher}

Centro em Rede de Investigação em Antropologia

\section{Printed version}

Date of publication: 1 November 2008

Number of pages: $503-521$

ISSN: 0873-6561

\section{Electronic reference}

João Leal, "A energia da antropologia: seis cartas de Jorge Dias para Ernesto Veiga de Oliveira",

Etnográfica [Online], vol. 12 (2) | 2008, Online since 04 July 2012, connection on 12 February 2022

URL: http://journals.openedition.org/etnografica/1814 ; DOI: https://doi.org/10.4000/etnografica.1814

\section{(c) (1) (8)}

Etnográfica is licensed under a Creative Commons Attribution-NonCommercial 4.0 International License. 


\section{A energia da antropologia. Seis cartas de Jorge Dias para Ernesto Veiga de Oliveira}

João Leal

Universidade Nova de Lisboa; Centro em Rede de Investigação em Antropologia

JORGE DIAS (1907-1973) MANTEVE AO LONGO DA VIDA UMA INTENSA correspondência - até agora inédita - com vários dos seus amigos, colaboradores e colegas. As seis cartas que a seguir são publicadas são dirigidas ao seu grande amigo e companheiro de equipa Ernesto Veiga de Oliveira. Foram escolhidas por Benjamim Pereira de entre um conjunto mais vasto de cartas e foram transcritas, com respeito pela grafia original, por Catarina Mira. O período que cobrem é um período extenso: a primeira carta foi escrita em 1939, quando Jorge Dias iniciava os seus estudos etnológicos em Munique, e a última data de 1959, quando Jorge Dias, já depois da reorientação africanista da sua pesquisa, desempenhou funções de professor visitante na Universidade de Witwatersrand em Joanesburgo. Uma dessas cartas - escrita em papel timbrado da Missão de Estudos das Minorias Étnicas do Ultramar Português - não está datada, mas tudo indica que tenha sido escrita no final dos anos 1950, antes da estada de Jorge Dias em Joanesburgo.

Cada leitor lerá as cartas de diferentes maneiras: como uma janela de entrada nos sentimentos e sonhos de Jorge Dias, como documentos informais sobre o seu percurso científico e o dos seus companheiros de trabalho, como testemunhos sobre o modo como as suas aspirações se cruzaram com os dilemas do seu tempo.

Pela minha parte houve dois ou três pontos a que fui mais sensível. Um deles tem a ver com o modo como as cartas documentam o fascínio de Jorge Dias por modos de vida alternativos, identificados com o campo e associados à 
errância, à liberdade e à plenitude. Em 1939, em Munique, escrevia a Ernesto Veiga de Oliveira: "Estou ávido por me deitar pelos montes fora, a beber a luz, porco, rôto, selvagem. Vai-me saber espantosamente bem ter uns mêses consigo. Havemos de nos asselvajar até à medula. [...] Havemos de percorrer essas regiões espantosas do País, lentamente, de saco às costas, a fazer a comida entre duas pedras, dormindo nos palheiros. Ouviremos aquelas vozes que quási emudeceram para nós, porque brutalizamos a nossa mais pura emotividade, com as lutas estúpidas a que nos temos sujeitado."

É desta energia quase libertária que nasce a antropologia em Jorge Dias. Em 1942, ainda na Alemanha - esse "mundo nórdico de névoas espessas e frios glaciais" - Jorge Dias fala já da antropologia como a possibilidade de realização profissional de um ideal de "vagabundagem" - expressão recorrentemente usada na sua correspondência - associado à liberdade dos grandes espaços campestres e serranos. A etnologia, escreve Jorge Dias a Ernesto Veiga de Oliveira em Julho de 1942, "é para nós uma possibilidade única porque nos dá liberdade para andarmos meses pelas serras e campos, com a certeza de ter o pão garantido na sociedade dos homens". Em Novembro de 1942 volta a insistir: "A Etnografia permite-nos viver pelos montes e pelas aldeias, sem termos um patrão, livres como desejamos e com a vantagem de termos uma recomendação do ministério e um ordenado todos os mêses."

Presente nos anos de formação de Jorge Dias, esta energia libertária, de fundo antimodernista, nunca mais o abandonou, como mostra uma carta do final dos anos 1950 em que Jorge Dias escreve: "Eu tenho passado estes dias na quinta e, coisa curiosa, começo a sentir-me cada vez melhor naquele vale solitário rodeado pela ameaça invisivel da civilização. Vivo ali como um vagabundo, inebriado com o aroma das plantas silvestres e com os cantos da passarada e de outros bichos. Sinto-me bem, e cada vez me sinto menos ligado às ambições que fervilham na cidade fedorenta, empomadada e engomada."

Testemunhando dessa energia que habita a vocação antropológica de Jorge Dias, as suas cartas para Ernesto Veiga de Oliveira falam também de alguns dos passos da transformação dessa energia em antropologia.

As cartas da Alemanha são essenciais para perceber as fases iniciais dessa transformação: as primeiras leituras, a oscilação terminológica entre etnografia, geografia humana e Volkskunde, os primeiros esboços de projectos, como quando Jorge Dias escreve a Ernesto Veiga de Oliveira, enfaticamente: "não quero que Você abandone o seu curso, pois convem ter uma licenciatura em Letras [...]. Os trabalhos a fazer são de vária ordem e muito vastos e entre outras coisas convem uma certa cultura filológica, pois talvez valesse a pêna fazer o mapa linguístico de Portugal." Da mesma forma, em Novembro de 1942, antecipando o seu regresso a Portugal, Jorge Dias desafia Ernesto Veiga de Oliveira para um primeiro exercício de etnografia vagabunda: "Estas férias já devíamos vaguear muito por serras do norte, para possivelmente publicarmos 
qualquer coisa juntos antes da sua licenciatura e depois meu caro Ernesto, a nossa vida será lado a lado, por serras e vales, pelas praias cheias de sol, pelas romarias coloridas e barulhentas e pelos grandes planaltos silenciosos e desertos em que velhos pastores perpetuam costumes milenários."

Quanto às cartas de final dos anos 1950, surpreendem vários momentos dessa energia já transformada em antropologia concreta. Alguns desses momentos são institucionais. É o caso da criação do Centro de Estudos de Etnologia, ao qual repetidamente Jorge Dias regressa nas suas cartas. Na carta não datada de final dos anos 1950 refere-se-lhe ainda, de forma algo contida, como um Centro que deverá "estudar diferentes aspectos da cultura das sociedades humanas e em especial do pôvo português nas várias regiões da terra em que se encontra fixado". Mais tarde, em carta de Dezembro de 1959, transparece já o entusiasmo pela obra realizada no quadro do Centro: "Afinal, a gente pode ter a certeza de que o nosso Centro vem a realizar uma obra única no país, e com recursos extremamente modestos. Ou eu me engano muito, ou daqui a uns dez anos o nosso Centro é uma instituição notável no país pela obra realizada. É tudo uma questão de orientar bem o trabalho e de trabalhar com perseverança."

Simultaneamente, as cartas de final dos anos 1950 documentam vários momentos do desenvolvimento das pesquisas concretas às quais se abalançavam então Jorge Dias e os seus companheiros. A pesquisa relativa aos espigueiros, que estaria na origem do clássico Espigueiros Portugueses (1963), é várias vezes referida, como na carta de Dezembro de 1959: "Gostei de saber que Vocês sempre estão decididos a atirarem-se aos espigueiros. Eu tenho hoje muitos elementos sôbre o assunto de muitas partes do mundo: Africa, America do Sul, Centro e Norte, e Oriente. Creio que possa trazer alguns elementos novos sôbre o caso. Não sei se o faça já, juntamente convosco, ou se publique mais tarde. De qualquer maneira o vosso tem de aparecer antes ou ao mesmo tempo, pois a parte especulativa deve seguir-se a parte descritiva e analítica." As pesquisas de Ernesto Veiga de Oliveira sobre a arquitectura popular em Portugal são também referenciadas. Depois de referir uma deslocação de Orlando Ribeiro a Tavira para estudar os "telhados a 4 águas, tipo pombalino, com características orientais", Jorge Dias escreve a Ernesto Veiga de Oliveira: "Isto mostra a importância dos estudos da habitação que Vocês têm vindo a fazer com extraordinário rigor, mas que por enquanto está limitado ao litoral do Norte. É preciso estender a vossa actividade a outras áreas do país."

Por vezes são anunciados projectos que nunca chegaram a ser concretizados, como a ideia de escrever "uma pequena monografia sobre as constantes da actividade industrial do povo portugues". Noutros casos assinalam-se novas possibilidades técnicas - o carro, uma Leika - que permitiriam projectar a pesquisa para novos patamares de exigência. Há uma menção à reorientação africanista da pesquisa de Jorge Dias, que se lamenta a esse propósito por ter 
abandonado os seus companheiros de trabalho "para seguir tão desvairados caminhos". A integração de Benjamim Pereira - "seguro, sereno e de olhinho vivo e sempre alerta" - na equipa de trabalho do Centro é também objecto de várias referências: "Ele é um excelente moço e tenho a certeza que havemos de fazer dele um bom etnógrafo. Eu simpatizei logo que o vi pela primeira vez, mas agora não tenho a mínima duvida de que está ali uma pérola. Se tu o fores ajudando e pulindo, orientando convenientemente a sua actividade e sujerindo alguma leitura havemos de fazer dele um magnífico colaborador."

Tomadas no seu conjunto, estas referências - e outras que o leitor terá ocasião de descobrir por si próprio - mostram-nos um Jorge Dias irrequieto na sua ânsia de fazer da antropologia um espaço de movimento e de "perseverança" aberto a novos desafios. Ainda hoje somos devedores - em Portugal - dessa energia que transformou a "vagabundagem" numa "disciplina" que faz da visitação de universos culturais diferentes o seu motivo inspirador.

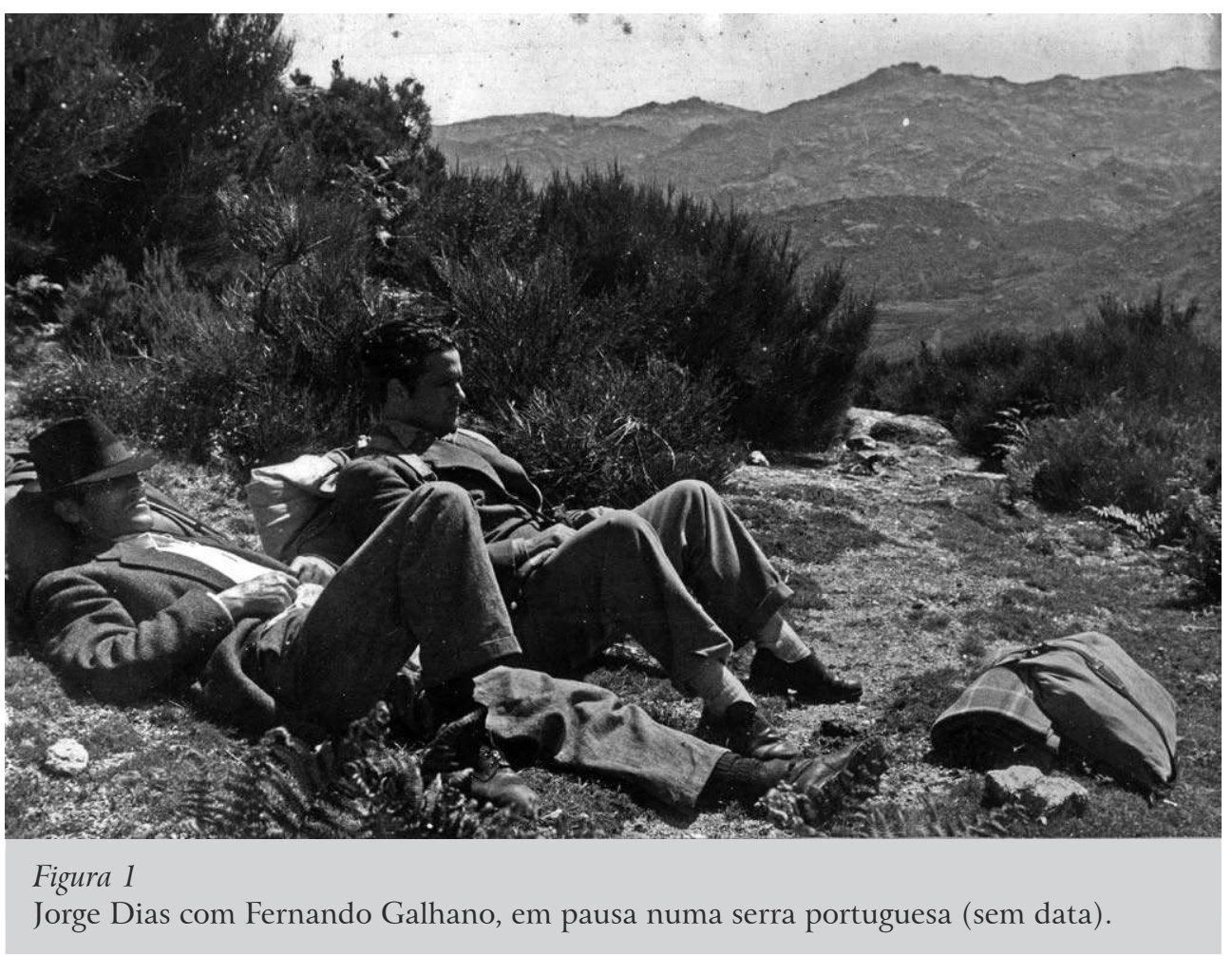


Munique, 20-VI-39

\section{Caro Ernesto!}

Como sempre, a sua carta trouxe-me um sôpro de vida estranha. Você mesmo quando está mais desanimado, tem o condão de me dar força e animar. E digo dar força, porque, para mim as coisas nem sempre valem o que valem para os outros. Com respeito à sua convicção de que a minha situação aqui é definitiva, digo-lhe que se engana. Eu não aturo isto muito tempo. A cultura é muito bonita, as pessoas são muito ilustradas, há muita arte, etc. Mas falta-me o essencial: a vida livre e plena das montanhas da minha terra. Nós somos feitos de lôdo, e é-nos indispensável viver em contacto com o resto da terra de que saimos. Eu estou agora convencido, de que a única coisa para mim verdadeira é a vagabundagem. Sinto-me a abafar no meio desta gente e entalado nos moldes estreitos da responsabilidade dum lugar de professor. Isto de ter de falar sempre a sério, com pessoas sempre sérias, é uma estopada. Depois tudo isto é muito bonito, mas são parques e jardins. O que eu quero é uma Natureza natural e não Natureza artifício. Estou ávido por me deitar pelos montes fora, a beber a luz, porco, rôto, selvagem. Vai-me saber espantosamente bem ter uns mêses consigo. Havemos de nos asselvajar até à medula. Depois vimos até Munique dar os últimos retoques à chamada cultura e por fim cairemos para sempre na verdadeira vida.

Eu recebi hoje um convite para fazer um método de português para alemães. Vou àmanhã procurar o director da empresa que me convida para saber as condições. Como espero deve-me dar uns contos de reis. Ora porque não há-de Você vir comigo em fins de Outubro ajudar-me no trabalho e ganhar o suficiente para viver? Passa aqui uns mêses, e talvez arrange a ficar tanto tempo como eu, e depois havemos de arranjar em Portugal qualquer coisa que nos permita viver e escrever. Nós devemos ter possibilidade de o fazer. Por si não duvido. Querendo trabalhar Você dá um escritor extraordinário. Mas mesmo em arte é preciso dispender energia, e o que o matou foi a falta de entusiasmo e método. Você não é um poeta lírico como o Eduardo, em que a inspiração é indispensável mas não exige regularidade de trabalho. Você deve criar uma obra em que a emoção se case com a razão. Deixe-me estar consigo e vai ver. Estou cheio de esperança.

Acho bem Você ganhar forças, mas isso não se consegue fazendo as brutalidades que fez com o Eduardo e o Galhano. Durante uma grande temporada não deve fazer grandes esforços. Coma, durma, passeie, sonhe e espere por mim. Havemos de percorrer essas regiões espantosas do País, lentamente, de saco às 
costas, a fazer a comida entre duas pedras, dormindo nos palheiros. Ouviremos aquelas vozes que quási emudeceram para nós, porque brutalizamos a nossa mais pura emotividade, com as lutas estúpidas a que nos temos sujeitado. Vamos primeiro ao Minho, só para pastar. Tomamos lá um banho de verdura. Depois de bem frescos vamos até Trás-os-Montes purificar a alma, eleva-la aos grandes ideais e à compreenção de Deus. A seguir uns dias de Gralheira, para matar a sede nas bicas puras da serra. Daí vamos para a Beira Baixa, região do Sabugal, seguindo a fronteira espanhola vindo a acabar no cimo da Serra da Estrela. Para isto não é preciso muito dinheiro, mas sempre é necessário algum. Vá-se portanto prevenindo, pois a sua mãe não lhe recusa algum e vai ser um tempo de enlouquecer. Enquanto descansa vá lendo livros do Knut Hamsun, para enriquecer a alma com o sônho desse aventureiro. Depois basta o nosso sônho. Entregues a nós próprios desfraldaremos as velas da fantasia aos ventos da serra e pairaremos por todas as paisagens como Nill Olgerson quando cavalgava o ganso bravo. O Eduardo disse-me que estava resolvido a dar-me algum tempo seu. Portanto iremos com êle e o Galhano a algumas regiões, se êles não quiserem vaguear sempre, vamos nós, sòzinhos como dois pegureiros ansiosos de luz e graça de Deus.

Isto aqui com respeito a clima é miserável. Ainda não sei se estou na Primavera ou no Inverno. De dez, em dez dias de chuva vem um de sol. A monotonia dos tons pardos chega a fazer enlouquecer. Tenho uma ânsia de cores vivas que deslumbrem como um tesoiro maravilhoso a brilhar ao sol.

Se nós arranjarmos qualquer coisa que nos de de comer numa aldeola nossa. Tendo liberdade e podendo escrever, talvez seja possível atingirmos um ideal ambicionado e que hoje parece de impossível realização.

De saudades ao Eduardo

Abraça-o com toda a amizade o eterno companheiro do destino

$\mathrm{Ant}^{\mathrm{O}}$ 
Bernau, den 25. Juli 1942

Meu querido Ernesto,

Até que enfim recebo um sinal de vida seu! Contudo, eu não acho estranho o seu silêncio, até me parece natural. Para si esta minha vida deve ter qualquer coisa de irreal e fantástico, uma espécie de realização dum sonho impossível. Para mim não existe mistério, porque a minha vida aqui tem o caracter banal do cotidiano, e a sua é-me conhecida porque se desenrola no teatro em que eu tantos anos representei uma apagada figura de tragi-comédia. Por isso, enquanto que eu ligo perfeitamente o nosso passado ao presente, Você está na margem de lá a tatear no escuro e a idealizar a minha fantástica existência.

Eu estou em vésperas de partida, pois dentro duns dez dias devo estar em Portugal. Não me faltam projectos e escusado será dizer que Vocês estão sempre associados a êles, só me falta saber se as circunstâncias não nos impedirão de realizar o desejado.

Não me parece que os nossos destinos tendam a separar-se e eu cada vez o associo mais aos meus planos futuros, alegrando-me bastante os seus triunfos académicos presentes. Eu sei que êles nada valem para si e que Você não trabalhou para as classificações que tirou, mas de qualquer maneira é uma satisfação ser-se bem sucedido e sobretudo interessa-me muito o facto de Você tirar boas classificações, porque isso vem ajudar os meus planos. Como lhe disse o ano passado, continuo a pensar em dedicar-me à Geografia Humana; isto é a uma coisa que aqui se estuda sob o nome de Volkskunde, e que tem por base a Geografia Humana se bem que uma extensão maior e muito maior profundidade. O estudo é em si interessante, tem no nosso país fontes imensas por estudar e é talvez a profissão mais compatível com a nossa maneira de ser e com as duras realidades da vida a que não podemos fugir. Nós temos de ver as coisas de frente e compreender que o nosso desejo romântico de vagabundagem é no nosso século uma utopia, se é que não será utopia em tôdas as épocas. Portanto, é indispensável harmonizarmos o nosso temperamento e a profissão, escolhendo uma que não seja incompatível com êle e seja ao mesmo tempo uma possível na nossa sociedade. A Volkskunde é para nós uma possibilidade única, porque nos dá liberdade, para andarmos mêses pelas serras e campos, com a certeza de ter o pão garantido e um lugar na sociedade dos homens. Além disso, passariamos uns quatro mêses todos os anos em Lisboa o que não deixa de ser necessário, para não perder o contacto com o outro lado das coisas. 
Eu penso fazer o meu doutoramento em março do próximo ano e ainda ficarei mais uns mêses a trabalhar aqui com quem percebe do assunto, para depois poder trabalhar aí com uma certa segurança. Naturalmente que me seria utilíssima a sua colaboração e só lamento que Você não possa trabalhar aqui um ano comigo, mas se bem que eu the arranjasse isso com facilidade, não quero que Você abandone o seu curso, pois convem ter uma licenciatura em Letras para poder melhor propor-se à candidatura do lugar. Os trabalhos a fazer são de vária ordem e muito vastos e entre outras coisas convem uma certa cultura filológica, pois talvez valesse a pêna fazer o mapa linguístico de Portugal. Mas sôbre estas coisas falaremos quando eu fôr.

Como Você deve calcular, devemos encontrar muitas dificuldades pela frente e é indispensável uma grande coragem e fôrça de vontade para vencer a resistência dessa gente dos ministérios, mas eu creio na minha estrêla e na minha audácia. A sua atitude confiante e optimista nesta última carta foi uma grande satisfação para mim, que confio bastante em si, como o companheiro ideal para uma tal realização. Você para o ano já deve concluir as cadeiras da licenciatura e só lhe falta a tese. Quem sabe se um motivo da Volkskunde vista por um aspecto filosófico seria uma maneira de matar dois coelhos de uma só cajadada! Bem, esperamos mais uns dias para conversar.

Saüdades ao Eduardo e ao Carlos se o vir

Abraça-o do coração o seu $\mathrm{mt}^{\mathrm{o}}$ amigo $\mathrm{Ant}^{\mathrm{o}}$

P. S. Cumprimentos da Margot 
Bernau, 20-XI-42

Meu querido Ernesto,

O regresso a êste mundo nórdico de névoas espessas e frios glaciais fez-me imediatamente cair naquele segundo eu, que cá se foi a pouco e pouco formando, em contacto com outra cultura e com outra paisagem. A mutação é rápida: um raio de sol quente, um copo de vinho e a vozearia meridional chamam-me imediatamente àqueles estados de consciência habituais na minha infância e mocidade. Da mesma maneira que esta paisagem grande e fria, esta gente ponderada e romântica, idealista e culta me obrigam a tomar perante a vida uma nova atitude; mais reflectida; mais lucida e ordenada, mais positiva e activa e decididamente mais útil. Não falo aqui duma utilidade social, refiro-me simplesmente ao meu eu, ao complexo psicológico que sou e que naturalmente encontra uma maior possibilidade de expansão e equilíbrio neste ambiente tão rico de personalidades e de possibilidades.

Pouco tempo depois de cá chegar já estava às voltas com os livros e para não me meter bruscamente ao trabalho, resolvi, como introdução, ler alguma coisa, que pudesse servir para a sua futura tese. E não lhe digo nada, passei umas horas deliciosas, que tive de interromper porque urge aproveitar o tempo que tenho até começarem as aulas, para rever o meu trabalho. Li só dois livros um de Kurt Schneider: Die Psycchopatischen Persönlichkeiten e o outro de Kretschmer Geniale Menschen. Os titulos não parecem ir direitos ao nosso assunto e contudo Você não faz ideia da riqueza de sugestões que aí se encontram, sobretudo no último. Ele desenvolve uma teoria psicológica àcerca das raças, interessantíssima e que Você podia aplicar a Portugal, estabelecendo possívelmente um paralelo entre o nosso país e a nação visinha. Enfim, só lhe sei dizer que pelos começos que tive estou convencido duma magnífica zona de explorações que podem dar lugar a uma tese magnífica. Você leia um pouco alemão e procure ir dominando a língua. É indispensável que nós não nos deixemos dominar pela parte fraca do nosso eu e levemos ao fim os nossos projectos e para isso é indispensável trabalhar com regularidade e ter bastante confiança em nós e no futuro. Nós somos no fundo dois grandes vagabundos de olhos extasiados perante o mistério da vida. Mas se o somos e sempre seremos, não quere isto dizer que desistamos da vida, pelo facto de ela oferecer poucas possibilidades para gente como nós. Se nós quisermos, Ernesto, havemos de conseguir uma situação ideal para a nossa maneira de ser, simplesmente com a obrigação de darmos um certo 
esforço para alcançarmos o nosso fim. A Etnografia permite-nos viver pelos montes e pelas aldeias, sem termos um patrão, livres como desejamos e com a vantagem de termos uma recomendação do ministério e um ordenado todos os mêses. Isto é, naturalmente, uma grande limitação e não corresponde àquilo que um dia sonhamos, mas isso é um absurdo. Os nossos sonhos românticos não são realizáveis e se ficássemos agarrados a êles só conseguíamos sossobrar nêste atoleiro que é a vida moderna. Hoje poetas e sonhadores, filósofos e pensadores só vivem quando conseguem uma forma de actividade acessória que lhes assegure a existência. Ou se é professor ou jornalista, ou tradutor, enfim qualquer roda da grande engrenagem social, cuja função é reconhecida. Ora nós temos de aceitar isto como uma grande realidade e parece que já ambos não temos dúvidas sôbre o assunto. Resta-nos portanto procurar a solução. Quanto a mim encontrei esta, que se não é ideal é das melhores que até hoje se me apresentaram. Vim porém à conclusão, que sósinho nunca serei capaz, assim como Você sósinho não será capaz de muita coisa. Está portanto indicado que temos de nos associar nesta vida, para juntos a levar mais facilmente. O ideal até seria três, ou quatro, pois venciamos melhor todos os obstáculos que surgem constantemente, mas creio que se formos mais de dois não conseguiremos quem nos pague. O nosso país é muito pobre, para pagar tais luxos. Por isso, temos de ter coragem e metermo-nos ao barulho. Você, por enquanto, vai concluindo o curso e faz uma tese que tenha relação com os trabalhos a que se quere propor e depois arranjaremos a que nos deem uma situação oficial. A época é a melhor para êstes estudos, pois o que se não fizer nestes decénios nunca mais se fará, porque desaparecerão todos os restos das velhas tradições. Estas férias já devíamos vaguear muito por serras do norte, para possivelmente publicarmos qualquer coisa juntos antes da sua licenciatura e depois meu caro Ernesto, a nossa vida será lado a lado, por serras e vales, pelas praias cheias de sol, pelas romarias coloridas e barulhentas e pelos grandes planaltos silenciosos e desertos em que velhos pastores perpetuam costumes milenários. Envelheceremos os dois por entre fragas, perdidos a ouvir a voz do vento e esquecidos de fazer trabalhos e livros para o pó das bibliotecas. Adeus meu querido Ernesto, até ao ano.

Saüdades a todos especialmente ao Eduardo meus e da Margot.

Abraça-o ternamente o seu

Antonio 
[Escrito em papel timbrado: University of the Witwatersrand, Joannesburg] 15 de Novembro de 1959

\section{Meu velho!}

Recebi ontem a tua carta cheia de moinhos e estive quasi a investir de lança em punho como o velho Quixote, não contra as velas, mas contra o destino, que me impediu de ter levado a tarefa a cabo há mais tempo! Mas eu no fundo não estou descontente com êle. No fundo adoro a vida, e tenho bebido a taça a trasbordar de tudo quanto ela oferece. Contudo, tenho muitas vezes pena de vos ter abandonado, para seguir tão desvairados caminhos. Por outro lado, se o não tivesse feito, e se os lugares que ocupo tivessem sido preenchidos por outros, género Fernando de Castro P.L., talvez já nem o nosso Centro existisse, porque afinal quem pauta, na nossa terra, é quem ocupa certos lugares estratégicos. Felizmente que Vocês seguiram os velhos trilhos etnográficos que eu tinha começado a rasgar, com tanta segurança e êxito, que eu já nada tenho a recear pelo futuro da nossa obra.

Se o Fernando me tivesse dito que o trabalho dos franceses devia aparecer ainda êste ano, eu tinha escrito umas linhas, pois não era coisa que me matasse. Mas eu pensei que tivesse mais tempo e com os materiais que tenho em casa, e com o que já lá tenho redigido, pensei poder escrever uma espécie de introdução à evolução da moagem durante as férias do Natal.

Mas afinal as coisas são outras e acho que fizeste muito bem em ter escrito o prefácio e em andar para a frente. Vocês já sabem que eu tenho muitos defeitos, mas acima de tudo sou Vosso amigo e companheiro e nunca quero ser um empata. O prefácio está muito bom, e eu não o escreveria tão bem, disso podes tu estar certo. Foi também um gesto de amizade tê-lo assinado por mim, mas podias perfeitamente tê-lo assinado tu. Bem sabes que eu ainda não estou como o Mendes Correia. Quanto a o teu nome figurar no livro acho uma excelente ideia, e já tencionava propô-lo ao Fernando, quando fôsse no Natal ao Porto. Nestes trabalhos a colaboração é dada da maneira mais variada, e as sujestões e conversas são tão importantes, como ter directamente escrito umas páginas do livro. Não calculas como me sinto feliz por ver os nomes de nós três associados na mesma obra. Se nos mantivermos sempre unidos havemos de conseguir que o nosso Centro venha a ser uma realidade aceite e respeitada por todos. A entrada do Benjamim é mais uma garantia de sucesso, e era um elemento que nos fazia muita falta - foi uma lança em Africa que há-de dar abundantes frutos. 
Eu acho que o Fernando devia fazer uns mapas com a distribuição dos moinhos em Portugal, como fez com os aparelhos de elevar a água de rega. Também não seria mau, no primeiro volume, levar umas boas fotografias de uma azenha e de moinhos. Podiamos mesmo comprar no Beleza ou no Alvão. Agora com a Laica já podemos tirar boas fotografias, mas as antigas nem sempre são muito aproveitáveis. Não seria bom fazer um índice analítico de toda a obra e publica-lo no último volume. Talvez conviesse dizê-lo no prefácio.

Parabens pela tua actividade e por tudo. Recebe um grande abraço do coração do Antonio. Dá saudades ao Benjamim.

P.S. Devo regressar a Lisboa no $1 .^{\circ}$ de Dezembro. Dá um abraço ao Fernando e diz-lhe que se agarre aos moinhos como um valente, e que faça uns mapas bonitos. No $1 .^{\circ}$ volume deve vir um com a distribuição dos tipos descritos. 
[Escrito em papel timbrado: University of the Witwatersrand, Joannesburg] 5 de Dezembro de 1959

Meu caro Ernesto,

Não calculas o prazer que tive com a vossa visita! Sinto-me tão feliz como tu com a aquisição do Benjamim. Ele é um excelente moço e tenho a certeza que havemos de fazer dele um bom etnógrafo. Eu simpatizei logo que o vi pela primeira vez, mas agora não tenho a mínima duvida de que está ali uma pérola. Se tu o fores ajudando e pulindo, orientando convenientemente a sua actividade e sujerindo alguma leitura havemos de fazer dele um magnífico colaborador.

Não sei se compreendes o que representa para mim ver que aqueles a quem dei a minha confiança correspondem de maneira tão cabal. Afinal, a gente pode ter a certeza de que o nosso Centro vem a realizar uma obra única no país, e com recursos extremamente modestos. Ou eu me engano muito, ou daqui a uns dez anos o nosso Centro é uma instituição notável no país pela obra realizada. É tudo uma questão de orientar bem o trabalho e de trabalhar com perseverança.

Eu estou agora numa fase melhor do que há um ano. A estadia em Joanesburgo deu-me novas forças e energia. As permanências demasiado longas em Portugal esgotam-me, mas uns meses fora da terra restituem-me a juventude. Hoje dei uma aula bestial! Parece que o Espírito Santo tinha descido sôbre mim e falei como um eluminada. E estou resolvido a não me deixar ir abaixo.

Quero trabalhar convosco e realizar uma obra bonita e ao mesmo tempo viver com uma certa beleza.

Tenho pena de não poder ter estado mais tempo convosco, e de não ter visitado os museus na vossa companhia. Mas espero vir a recuperar o perdido, quando aí for no Natal.

Estive a pensar no esquema de uma pequena monografia sôbre as constantes da actividade industrial do povo portugues e cheguei ao seguinte resultado.

I Fase inicial comunitária

II Transição; propriedade colectiva e individual

III Propriedade individual e trabalhos colectivos não remunerados

IV Industrias caseiras; artesanato

V Espírito qualitativo, incapacidade racionalizadora

VI Transição industrias caseiras para a verdadeira industrialização

VII Moagem 
VIII Tecelagem. Teares manuais e industrias de fiação e tecidos S. ${ }^{\text {to }}$ Tirso e Guimarães

IX Industrias de Guimarães \{Ciclo fechado: milho-bois-coiro-chifre-estrumes, resíduos de cortumes, pentes, cabos de facas, etc.

X Tecidos de lã, teares manuais, pisões, (rebanhos transumantes La mesta, etc.)

XI Problemas relativos à tecelagem, defeitos da industria de tecidos.

Tratado de Methwen. Sistema de controle!

XII Olararia e cerâmica

XIII Filigranas e ourives de prata

XIV Desenvolvimento do espírito quantitativo e racionalista

Bibliografia: Gama Barros,

Lê isto e introduz sujestões. Uma vez estabelecido o esquema e com alguma bibliografia podemos fazer ràpidamente uma pequena monografia orientadora.

II

Gostei de saber que Vocês sempre estão decididos a atirarem-se aos espigueiros. Eu tenho hoje muitos elementos sôbre o assunto de muitas partes do mundo: Africa, America do Sul, Centro e Norte, e Oriente. Creio que possa trazer alguns elementos novos sôbre o caso. Não sei se o faça já, juntamente convosco, ou se publique mais tarde. De qualquer maneira o vosso tem de aparecer antes ou ao mesmo tempo, pois a parte especulativa deve seguir-se a parte descritiva e analítica.

É preciso que Vocês não sejam mesquinhos em matéria de ilustração, como o foram com os moinhos. Uma obra destas vale imenso pela ilustração. Olha a obra do Pires de Lima? Ele não fez nada pessoalmente, mas teve o mérito de valorizar espantosamente o vosso trabalho com a ilustração. Vocês têm de compreender isto e não transigir. O Fernando nestas coisas tem sempre a mania de puxar para trás, mas a tua obrigação é puxar para a frente. Se assim não fizerem, para que serve todo esse documentário fotográfico do Centro? Pode dizer-se que é uma autêntica inutilidade e foi dinheiro roubado ao Estado, visto que não se chega a utilizar. Nada de mesquinhês!!

Acho optima a ideia do Benjamim estudar as rocas. Pode começar pelas de uma determinada região e, aos poucos, pode fazer todas as rocas de Portugal. Para um trabalho desses tambem é importante a ilustração e o Fernando podia fazer desenhos bonitos de várias rocas existentes em museus portugueses.

Soube hoje que o Orlando foi a Tavira para estudar os telhados das casas de Tavira. Não sei se te lembras, de uns telhados a 4 águas, tipo pombalino, com características orientais? Isto mostra a importância dos estudos da habitação 
que Vocês têm vindo a fazer com extraordinário rigor, mas que por enquanto está limitado ao litoral do Norte. É preciso estender a vossa actividade a outras áreas do país. Agora que Vocês têm o Benjamim convem pôr tudo em movimento. Com um carro é fácil estender êsse estudo a todo o país e fazer uma obra única.

Meu velho, desculpa todo este arrazoado, mas estou cheio de esperança de que o Centro vai entrar numa nova fase. Gostei de te ver alegre e cheio de brilho e de ver o Benjamim, seguro, sereno e de olhinho vivo e sempre alerta. Está na tua mão fazer dele um excelente etnógrafo.

Daqui a uns 15 dias estou no Porto! Tenciono demorar-me por lá umas duas ou três semanas e sinto-me feliz por estar êsse tempo junto de vós.

Dá três sôcos ao Don Fernando, saudades ao Benjamim e para ti um abraço muito apertado do amigo velho do coração

\section{Antonio}

P.S. Se escreveres ao Eduardo, manda-lhe um abraço meu Teu Ant $^{\circ}$ 


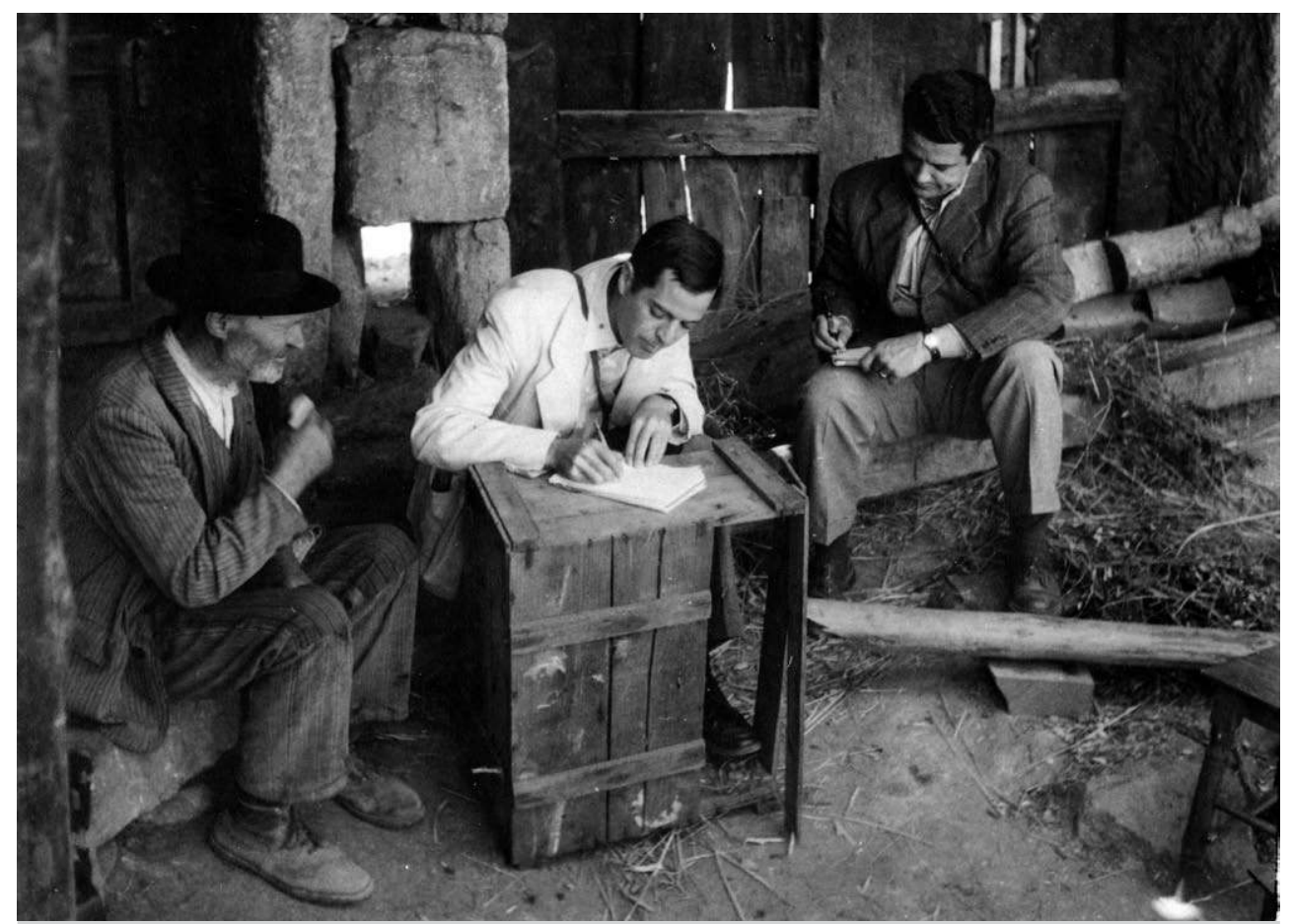

Figura 2 - «O prof. Wagley e Jorge Dias, num "cabanal” de uma velha casa de Felgar, ouvindo o Tio Domingos, latoeiro, cuja mulher era mordoma da igreja de Felgar (Junho de 1949)» (legenda no verso da fotografia original). 
[Escrito em papel timbrado:

Ministério do Ultramar

Centro de Estudos Políticos e Sociais

da Junta das Missões Geográficas e de Investigações do Ultramar

Missão de Estudos das Minorias Étnicas do Ultramar Português

Praça do Príncipe Real, 20 - Lisboa]

\section{Meu velho!}

Se tu tens saudades, eu nem se fala!! A viagem a Inglaterra, mesmo apesar da hostilidade de todos contra Portugal e dos negros, mesmo contra mim, sempre me fez bem. Eu tenho já esta deformação da personalidade; sem uma fuga para além fronteiras esmoreço e perco o sonho.

Eu preciso muito de falar contigo. Criou-se agora um Centro de Estudos de Antropologia Cultural, de que certamente vou ser director. Se Vocês vivessem mais perto eu metia-vos lá em melhores condições financeiras. Se eu tivesse confiança no futuro, obrigava-vos mesmo a vir para cá, mas quem é que hoje pode garantir qualquer coisa?! Contudo, trabalhar convosco era um grande prazer. Este Centro é para estudar diferentes aspectos da cultura das sociedades humanas e em especial do pôvo português nas várias regiões da terra em que se encontra fixado. Portanto cobre tambem o vosso campo. Mas não sei como há-de ser! Temos de conversar muito. Quanto a eu estar livre no momento, não é fácil, a não ser uns 3 ou 4 dias todas as semanas. Se viesses no dia 2 de Maio, é natural que no dia 3 não tenha aulas de manhã porque há uma conferência. Depois, de tarde tenho duas aulas e fico livre até ao dia 10 , porque na 3. ${ }^{a}$ feira 8 dou um ponto escrito e não preciso de lá estar. No dia 10 tenho aulas e volto a ficar livre (livre é claro, com pontos para ver) até ao dia 14, em que tenho reunião de curso em Coimbra. Podiamos talvez vir de carro para Coimbra de vagar por um caminho mais longo. Fico em Coimbra os dias 14 e 15. Com certeza, no dia 15 só fico de manhã pois de tarde vão todos no Cortejo da queima das fitas e eu já não tenho convicção para tanto e posso estar convosco ou regressar a Lisboa, pois no dia 17 tenho a última aula. Creio que tem de ser assim, de contrário, é necessário esperar até Junho. No S. João vou aí passar uns dias por causa do Congresso Luso-Espanhol. São sempre uma chatice, mas temos de fazer o sacrifício para receber a recompensa nos que se realizam em Espanha, muito mais do meu agrado, sejam com creadillas ou sem elas. 
Eu tenho passado estes dias na quinta e, coisa curiosa, começo a sentir-me cada vez melhor naquele vale solitário rodeado pela ameaça invisivel da civilização. Vivo ali como um vagabundo, inebriado com o aroma das plantas silvestres e com os cantos da passarada e de outros bichos. Sinto-me bem, e cada vez me sinto menos ligado às ambições que fervilham na cidade fedorenta, empomadada e engomada. Se eu Vos tivesse aqui era um rei sem reino mas com uma côrte de belos e fieis cortezãos.

Vem depressa e traz a tradução do hungaro para eu ver o que diz sôbre os espigueiros.

Saudades ao Benjamim e ao Eduardo

Abraça-te o teu Antonio. 


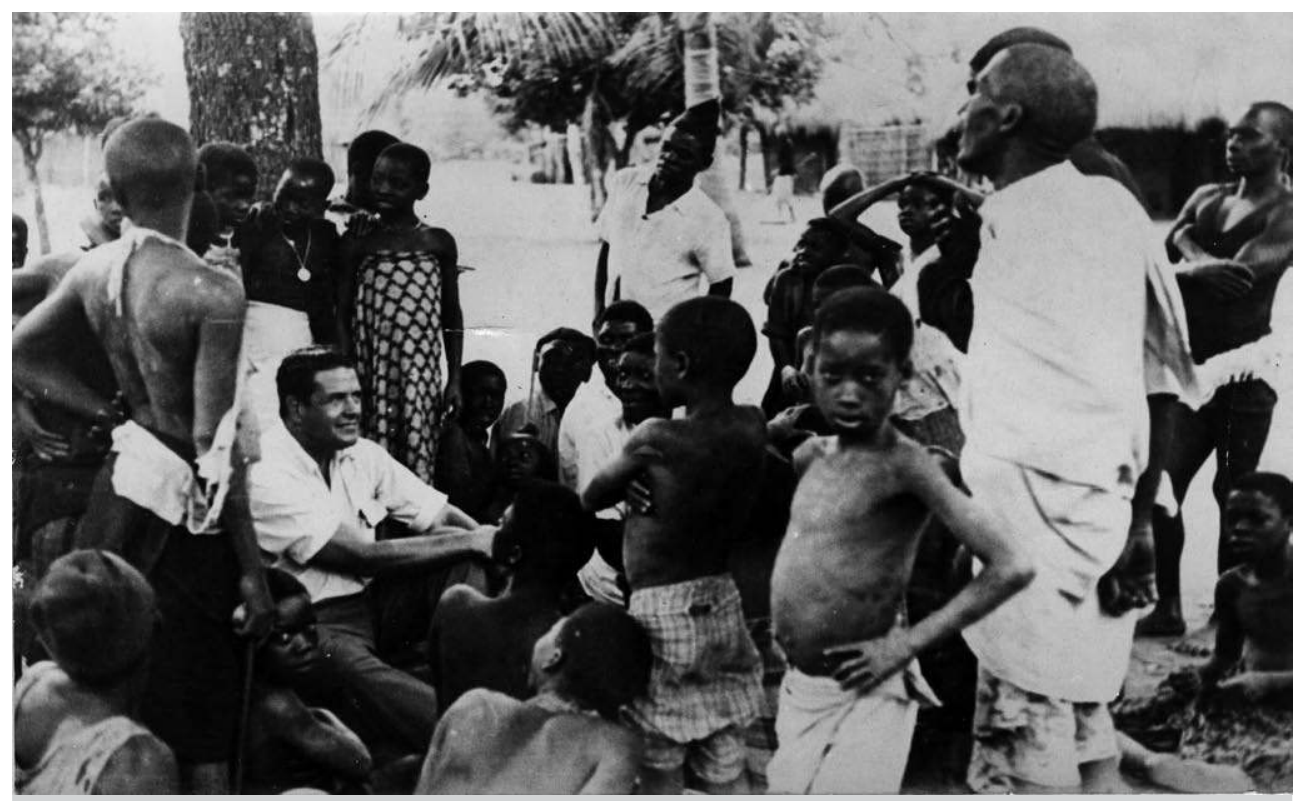

Figura 3 - Jorge Dias e macondes (1957). 